\title{
Estimating the prevalence of female genital mutilation in Portugal
}

Ana Lúcia Teixeira ${ }^{a}$, Manuel Lisboab

${ }^{a}$ Centro Interdisciplinar de Ciências Sociais CICS.NOVA - Faculdade de Ciências Sociais e Humanas - Universidade Nova de Lisboa (CICS.NOVA.FCSH/UNL); Avenida de Berna, 26-C, 1069-061 Lisboa, Portugal; Email: analuciateixeira@fcsh.unl.pt.

${ }^{\mathrm{b}}$ Centro Interdisciplinar de Ciências Sociais CICS.NOVA - Faculdade de Ciências Sociais e Humanas - Universidade Nova de Lisboa (CICS.NOVA.FCSH/UNL); Avenida de Berna, 26-C, 1069-061 Lisboa, Portugal; Email: m.lisboa@fcsh.unl.pt.

\section{Corresponding author:}

Ana L. Teixeira

Centro Interdisciplinar de Ciências Sociais CICS.NOVA - Faculdade de Ciências Sociais e Humanas - Universidade Nova de Lisboa (CICS.NOVA.FCSH/UNL); Avenida de Berna, 26-C, 1069-061 Lisboa, Portugal.

Email: analuciateixeira@fcsh.unl.pt; Telephone: + 351217958453.

Ana L. Teixeira contributed to the conception and the design of the study; gathered, analysed and interpreted the data; and drafted and revised the article.

Manuel Lisboa contributed to the conception and the design of the study; and revised the article.

Ana L. Teixeira and Manuel Lisboa both approve the submitted version of the article. 


\section{Abstract}

Objectives: Due to globalised migratory processes, female genital mutilation/cutting (FGM/C) has spread to other countries, namely in Europe, where, despite a few exceptions, it remains a concealed problem. This study estimates the prevalence of FGM/C in Portugal, being the first national extensive one on this issue.

Study design: Prevalence estimation.

Methods: Using the extrapolation of country of origin prevalence data method and the 2011 Census data, we estimated: FGM/C prevalence in Portugal for women in reproductive age and for all women aged 15 or older; and the number of girls (aged 0 to 14) living in Portugal who underwent or will probably undergo FGM/C.

Results: We estimate that a total of 6.576 women living in Portugal aged 15 or older have undergone FGM/C and are unevenly distributed across the national territory. Also, we estimate that 1.830 girls living in Portugal have already or will probably undergo FGM/C until the age of 15 .

Conclusions: We estimated that more than 6 thousand women are currently living in Portugal with the consequences of genital cutting and that there are many girls who are still at risk. Both these groups need different kinds of intervention. Knowing the dimension of the problem and its geographic configuration will enable a more informed and targeted definition of health public policies toward the protection of its victims and at-risk prevention.

Keywords: Prevalence; Female Genital Mutilation; Female Genital Cutting; Portugal 


\section{Introduction}

Female genital mutilation (FGM) or female genital cutting $(F G C)$ is widely recognized as a serious violation of human rights of women of all ages ${ }^{1}$. It constitutes a severe social genderbased problem, rooted in an imbalance of power between men and women, and it reflects one of the many forms of violence against women, representing society's control over women and perpetuating asymmetric normative gender roles harming women in multiple ways ${ }^{1,2}$. FGM/C, a traditional practice embedded in the cultural framework, is, for the practicing communities, considered a rite of passage to adulthood necessary to raise a girl properly and to prepare her for marriage $e^{1,3,4}$. It is associated with the control of women's bodies and sexuality by "guaranteeing" their virtue, fidelity, virginity, an enhancement of men's pleasure, and family honour ${ }^{4-9}$.

FGM/C has grievous consequences to women's and girls' sexuality (e.g., pain during intercourse, less sexual satisfaction), physical (e.g., recurrent urinary tract infections, childbirth complications) and psychological (e.g., anxiety, post-traumatic stress disorder) health, education, and empowerment ${ }^{4,10-13}$.

The World Health Organization defines FGM/C as "all procedures involving partial or total removal of the external female genitalia or other injury to the female genital organs for nonmedical reasons ${ }^{\prime 1}$. The same organization classified the diverse practices into four types of FGM/C: Type I (clitoridectomy) - partial or total removal of the clitoris and/or the prepuce; Type II (excision) - partial or total removal of the clitoris and the labia minora, with or without excision of the labia majora; Type III (infibulation) - narrowing of the vaginal orifice with creation of a covering seal by cutting and appositioning the labia minora and/or the labia majora, with or without excision of the clitoris; and Type IV - all other harmful procedures to the female genitalia for non-medical purposes, such as pricking, piercing, incising, scraping, and cauterizing. 
FGM/C is documented in 29 countries in Africa and Middle East although there are reports of FGM/C in many others, such as Mozambique, Malaysia, Israel, and Colombia ${ }^{14-17}$. A recent study has documented type IV FGM/C in the Tete province, Mozambique, where it is common among young girls to elongate the labia minora (procedure locally designated as puxa-puxa, kukhuna or kupfuna). In this region, it is also common for girls and women to insert products or medicines in the vagina "in order to close, tighten or reduce the vaginal canal" ${ }^{14}$. The prevalence of FGM/C varies greatly among the different countries and overall it is estimated that 100 to 140 million girls and women have already undergone $\mathrm{FGM} / \mathrm{C}^{1}$ and that, globally, $90 \%$ of FGM/C include types I, II and IV, with type III making up for the remaining $10 \%^{18}$.

Our use of the FGM/C terminology is in line with the current research and debate among academics and international development and human rights agencies. The term "mutilation" was first used by the Inter-African Committee on Traditional Practices Affecting the Health of Women and Children in order to emphasize the seriousness of this practice and to distinguish it from circumcision, and has been adopted by the majority of agencies and institutions working in the field. However, the term "mutilation" was also found to be judgmental and its use to be potentially disrespectful when working with practicing communities. So, a hybrid term - FGM/C (female genital mutilation/cutting) - is used in order to encompass all those meanings and sensibilities ${ }^{1,19}$. Specifically, this paper is intended to communicate a research project's results regarding the estimation of the prevalence of FGM/C in Portugal, and of the number of girls at risk of FGM/C currently living in Portugal.

Presently, there are few national studies in the European Union (EU) countries where the prevalence of FGM/C is estimated and Portugal is the eighth country to conduct such a study (among the 28 member states). This study thus contributes to data collection and discussion on this matter - a step which is "fundamental to targeted and evidence-based policy making 
and measures ${ }^{\prime 13}$ and to shed light on a concealed issue in terms of public action and debate, and its numbers and geographical dispersion.

In Portugal, several studies on FGM/C have already been conducted. However, these solely mobilized a qualitative perspective, based on case studies or specific communities ${ }^{6-8}$, from the medical and health care standpoint ${ }^{4,10,20}$, or on the theoretical discussion regarding the associated social processes and legal issues ${ }^{21,22}$. The aims of these analyses were mainly to uncover and to understand a reality still hidden in Portugal.

Now, drawing from a quantitative perspective, this study adds the estimation of the number of women, currently living in Portugal, who have undergone FGM/C and of the number of girls who have been submitted to this practice or will probably undergo FGM/C to this existing literature. 


\section{Methods}

We conducted a thorough review of the methodological options chosen by national studies on the prevalence of $\mathrm{FGM} / \mathrm{C}$ in the European Union with the aim of building a comparable knowledge set. Accordingly, we explored the strengths and limitations of prevalence studies from Italy ${ }^{23}$; Hungary ${ }^{24}$; Ireland ${ }^{25}$; Germany $^{26}$; The Netherlands ${ }^{27}$; Belgium ${ }^{28}$; and England and Wales $^{29}$.

We found that there was no common methodology and that we would be hard pressed to provide an estimate that could be directly comparable to existing national studies. Therefore, we chose to follow the most recent research methodologies, which have already benefitted from the latest debates on the field. Although all these studies used the extrapolation of country of origin prevalence data method, there were major differences regarding the counting of the populations mainly due to different conceptual approaches and data availability.

The extrapolation of country of origin prevalence data method, which was the one used to estimate FGM/C prevalence in Portugal, consists of multiplying the prevalence of the country of origin by the number of women born in each of those countries residing in Portugal. In short, we are applying the proportion of FGM/C of the country of origin to the host country. In order to compute more accurate estimates, we use age-specific prevalence to capture previous reported differences in $\mathrm{FGM} / \mathrm{C}$ prevalence among different age groups. In a strict sense, prevalence estimates regard only women in reproductive ages (15 to 49 years old). However, it was our aim to estimate the actual number of women currently living in Portugal with FGM/C. In order to do so, we also estimated its prevalence among women aged 50 or more. Since there are no prevalence estimates for this age group, we used the closest age specific prevalence (45-49 years). Finally, in order to estimate the number of girls, 0 to 14 years old, who have already undergone or will probably undergo FGM/C, we followed a similar 
approach, in line with the most recent national EU studies (e.g., in England and Wales ${ }^{29}$ ). Using the 2011 Census data, we considered the number of girls aged less than 15 years, living in Portugal, who were born in countries where $\mathrm{FGM} / \mathrm{C}$ is documented and the girls who were born in Portugal to mothers born in those same 29 countries. Although the father's family may, in some ethnic groups, have great influence on the decision of cutting the child, there is no sufficient and reliable data that would enable the inclusion of these specificities in the estimations. Thus, we used the same methodological approach as in the most recent international studies ${ }^{27-29}$, which is to consider solely the mother's country of birth. As there are no accurate prevalence estimates for this age group (0-14), we used the specific 15-19 years age group for the estimation.

\section{Data sources}

In order to employ the extrapolation of country of origin prevalence data method, we resorted to two different data sources: 1 ) the FGM/C prevalence in the country of origin, by age group; and 2) the number of women living in Portugal by country of birth and age. For the first data set, we used UNICEF's data compiled from different surveys, namely DHS (Demographic and Health Surveys), MICS (Multiple Indicator Cluster Surveys), RHS (Reproductive Health Surveys) and SHHS (Sudan Household Health Survey). FGM/C is documented in 29 African and Middle Eastern countries with available prevalence estimates by age group. These 29 countries can be clustered in 5 groups: 1) high prevalence countries (above 80\%), which include Somalia, Guinea, Djibouti, Egypt, Eritrea, Mali, Sierra Leone, and Sudan; 2) moderately high prevalence countries (51 to 80\%) including Gambia, Burkina Faso, Ethiopia, Mauritania, and Liberia; 3) moderately low prevalence countries (26 to 50\%) comprising Guinea-Bissau, Chad, Côte d'Ivoire, Kenya, Nigeria, and Senegal; 4) low prevalence countries (10 to 25\%), which include Central African Republic, Yemen, United Republic of 
Tanzania, and Benin; and, finally, 5) very low prevalence countries (below 10\%) including Iraq, Ghana, Togo, Niger, Cameroon, and Uganda.

Regarding data on the number of women and girls living in Portugal born in FGM/C practicing countries or born to mothers born in those countries, we used the latest Portuguese Census data (2011). Other sources, such as the national immigration office and the employment survey, were considered but found inadequate due to different constraints, namely the inexistence of information on the age group or other data for all the ages considered, a critical element for accurate prevalence estimations.

To estimate the prevalence of FGM/C in Portugal (women aged 15 to 49; plus women over 49 years), we compiled data on the resident population disaggregated by sex, age group, country of birth, and place of residence (region and municipality). We used the country of birth criterion and not nationality because a large parcel of these women may already have Portuguese citizenship (this is particularly common for women from Guinea Bissau, a former Portuguese colonial territory). 


\section{Results}

Working through the 2011 Census data, we found a total number of 10.617 women born in FGM/C practicing countries living in Portugal, aged 15 to 49 years. When adding the female population over 49 years, we reach a total of 13.335 women.

Analysing the same data disaggregated by country of birth, we found that $89 \%$ of these women (in reproductive ages) come from Guinea-Bissau ( 9.452 women). Guinea-Bissau is, by far, the larger migrant community in Portugal among these 29 practicing countries, given the former colonial liaison and the current language proximity to Portugal. Other countries represent a considerably smaller percentage: we found 395 women from Senegal (3,7\%); 161 from Guinea (1,5\%); and 136 from Nigeria (1,3\%). This distribution, including the remaining practicing countries, is presented below (table 1).

(Insert table 1)

Extrapolating the age group specific prevalence of each country of birth to the number of women, currently living in Portugal, born in the documented practicing countries, we estimate that 5.246 women living in the Portuguese territory, aged between 15 and 49 years, have been subjected to FGM/C (table 2).

If one also considers the female migrant population aged 50 or older, the women born in those 29 countries and that are 15 or older represent a total of 13.335 (10.617 women aged between $15-49$ years old, plus 2.718 women that are 50 or older). Extrapolating the prevalence of the $45-49$ age group to the 2.718 women aged 50 or older, we estimate that, among these, 1.330 women have probably been subjected to FGM/C.

Therefore, adding up these figures, we estimate a total of 6.576 women, aged 15 or older, that have undergone $\mathrm{FGM} / \mathrm{C}$, currently living in Portugal (table 2). 
(Insert table 2)

We did not find, however, a uniform distribution of these women over the Portuguese territory: they are concentrated mainly in the Lisbon district (more than two thirds), while 14\% live in Setúbal, an industrial region south of Lisbon (figure 1). Even within the Lisbon district, these communities tend to concentrate on five of its 16 municipalities: one-third in Sintra, 14\% in Loures, $12 \%$ in Odivelas, $12 \%$ in Amadora, and $11 \%$ in the Lisbon municipality proper. Together, they congregate $84 \%$ of Lisbon districts' prevalence. This observation is crucial for the definition of more targeted local policies and priorities regarding prevention and women's health care.

(Insert figure 1)

Regarding the number of girls who have undergone or will probably undergo FGM/C, we resorted to the same data source in order to reach comparable and coherent results. According to the 2011 Census, there were a total of 3.832 girls living in Portugal who were either born in FGM/C practicing countries (1.273) or born to mothers originating from those countries (2.559).

Although the effect of migrating to a foreign country should contribute to the decrease of this practice (as we will discuss below), we were not able to quantitatively include this effect in our estimation. There is no standard methodology to quantify the qualitative information that we can compile on this matter ${ }^{13}$. Among the national prevalence studies currently available in the EU, only the Italian tried to adjust their prevalence estimates by modifying the average FGM/C practicing countries' prevalence used in the extrapolation method. However, since no 
methodological description of the procedure is provides, we are not able to access its validity or applicability to other contexts ${ }^{23}$.

Using the extrapolation of country of origin prevalence data method, and using the specific 1519 years old age group prevalence, we estimated that 1.830 girls living in Portugal have already or will probably undergo FGM/C until the age of 15 (table 3).

(Insert table 3)

Altogether, these data show that the prevalence of FGM/C in Portugal is $49 \%$, meaning that we estimated that 5.246 of the 10.617 women in reproductive ages, from $\mathrm{FGM} / \mathrm{C}$ practicing countries, living in Portugal, have been subjected to this practice. Overall, and also considering women aged 50 or older, this figure rises to 6.576 women. Regarding the girls who have already undergone or will probably undergo $\mathrm{FGM} / \mathrm{C}$, we estimate that there are 1.830 girls living in Portugal, born in FGM/C practicing countries or born to mothers from those countries, in this circumstance.

These women, who have been subjected to FGM/C, will probably need specific medical attention. Since different studies have identified the need for specialized medical knowledge on this matter ${ }^{4,20,30}$, in line with other European countries ${ }^{31}$, knowing how many cases and where they are located could make the training of health care professionals become more effective.

Although this may not represent a quantitatively major issue in Portugal (compared with the numbers concerning violence against women, which tell us that one in three women was a victim of physical, psychological, and/or sexual violence ${ }^{32}$ ), it is still a matter of great concern, as it symbolizes a severe form of gender-based violence that perpetuates power asymmetries between men and women. 


\section{Discussion}

This study, which was the first national extensive one on this matter, aimed to estimate the prevalence of $\mathrm{FGM} / \mathrm{C}$ in Portugal. We were able to estimate that there are 6.576 women living in Portugal who were subjected to FGM/C (5.246 aged 15 to 49; and 1.330 aged 50 or older). We estimate that 1.830 girls living in Portugal have already or will probably undergo FGM/C until the age of 15 .

The currently available national prevalence studies in the EU reveal prevalences ranging from 27 to $48 \%{ }^{23-28}$. However, due to different methodological and conceptual approaches, these data are not comparable to ours, except for the most recent study from England and Wales ${ }^{29}$. Portuguese prevalence (49\%) is in line with the one found in these two countries (48\%), yet two very different realities emerge in absolute terms: while, in Portugal, these $49 \%$ represent 5.246 women, in England and Wales 48\% represent 137.000 women.

In order to overcome these comparison limitations, a standard cross-country methodology is being developed, under a DAHNE Funding Program, by the University of Ghent in collaboration with the Institut National d'Etudes Démographiques (France), and the Department of Sociology of the Università degli Studi di Milano-Bicocca (Italy). Results are expected by the end of 2016.

As previously suggested ${ }^{33}, \mathrm{FGM} / \mathrm{C}$ prevalence tends to be reduced outside the communities of origin, due to a higher access to information and education resources, lower peer pressure, and the knowledge of a penalizing law in the host countries (in Portugal, FGM/C has recently been defined as an autonomous criminal offense, as per Law $n=83 / 2015$, August $5^{\text {th }}$, Article $144^{\circ}$ A). However, the current study could not address this issue in a quantitative manner due to the time constraints that limited our methodological options. Hence, our prevalence estimates do not reflect the putative impact of migration even though this issue was addressed on the qualitative dimension of the broader research ${ }^{34}$ through in-depth interviews 
(which took place in 2014 and 2015). The interviewees have shown some ambivalence regarding this specific matter. On the one hand, many of them believe that leaving their country and their community will relieve the social pressure to continue this tradition. This is due to integration and acculturation processes, as well as access to education, an important factor to raise critical reflexivity, and to symbolically deconstruct this practice. On the other hand, some of them state that this practice may represent one of the means of preserving a cultural connection to their birth communities.

Therefore, in order to clarify immigration impact on FGM/C prevalence and to have more accurate estimates, upcoming studies should include this important dimension with a solid methodological foundation, namely by resorting to methodologies oriented for hard to reach populations, such as time-location sampling or response-driven sampling ${ }^{35,36}$. The current study did not include numbers on refugees or asylum seekers since the responsible institution for this data was not able to provide disaggregated data. In any case, we analysed the United Nations' Refugee Agency's reports and the presented figures do not show Portugal as one of the major host countries for these populations ${ }^{37}$ (Portugal is not even referred to in the UNHCR update report of $2014^{38}$; in 2014, 42 women from FGM/C practicing countries requested asylum $\left.{ }^{39}\right)$.Hence, the lack of this information should not have a major impact on the global figures presented in this study.

Despite the above mentioned shortcomings, we were able to access highly disaggregated data - prevalence by age group, by country of birth, by district, and by municipality - which is very useful in identifying lifecycle specific needs for medical care and social services, and in providing regional and local institutions (NGOs, health care services, schools) with more specific information on the extent of the phenomenon in their territories. Precisely because this practice has major consequences on its victims' health throughout their life, it is crucial that the access to, and the support from, health services are easily facilitated, this not being only a matter of human rights but also one of public health ${ }^{40}$. 
This study has shown the magnitude and the geographic distribution of FGM/C in Portugal, a crucial set of information for a targeted definition of health public policies, as depicted in the $3^{\text {rd }}$ Programme of Action for the Prevention and Elimination of Female Genital Mutilation, in the framework of the $5^{\text {th }}$ National Plan to Prevent and Combat Domestic and Gender-based Violence. Unveiling this reality constitutes an important step towards increasing awareness. This will ultimately contribute to the eradication of FGM/C, one of the many faces of genderbased violence, and its harmful physical and psychological health consequences. 


\section{Acknowledgements}

The authors wish to thank the project's team members, without whom this research wouldn't have been possible. We are also thankful to Ana Ferreira for valuable review of the current paper.

Funding: Fundação para a Ciência e a Tecnologia's research project grant FACC - Proc. № 157 236.

Competing interests: None declared.

Ethical approval: Not required. This article does not contain any studies with human participants or animals performed by any of the authors. 


\section{References}

1. World Health Organization (WHO). Eliminating female genital mutilation: An interagency statement. OHCHR, UNAIDS, UNDP, UNECA, UNESCO, UNFPA, UNHCR, UNICEF, UNIFEM, WHO. Geneva: WHO; 2008.

2. United Nations General Assembly. Declaration on the Elimination of Violence against Women [A/RES/48/104]. 1993.

3. Mackie G. Female genital cutting: the beginning of the end. In: Shell-Duncan B, Hernlund Y, editors. Female "circumcision" in Africa: culture, controversy, and change, Colorado: Lynne Rienner Publishers; 2000, p. 253-82.

4. Gonçalves Y. Mutilação genital feminina. Lisboa: Associação para o Planeamento da Família; 2004.

5. Yoder PS, Camara PO, Soumaoro B. Female genital cutting and coming of age in Guinea. Calverton, Maryland, U.S A.: Macro International Inc.; 1999.

6. Branco S. Cicatrizes de mulher. Lisboa: Público; 2006.

7. Oberreiter JA. A cut for lifetime. The case of female genital mutilation among the community of Guinea Bissau in Lisbon [Master's thesis]. Lisboa: Faculdade de Direito da Universidade Nova Lisboa; 2008.

8. Martingo C. O corte dos genitais femininos em Portugal: o caso das guineenses. Lisboa: Alto Comissariado para a Imigração e Diálogo Intercultural; 2009.

9. Brown K, Beecham D, Barrett H. The Applicability of Behaviour Change in Intervention Programmes Targeted at Ending Female Genital Mutilation in the EU: Integrating Social Cognitive and Community Level Approaches. Obstetrics and Gynecology International 2013;2013:1-12.

10. Campos AC. Mutilação genital feminina - a importância de reconhecer e de saber como agir. Acta Obstet Ginecol Port 2010;4:152-6. 
11. World Health Organization (WHO). Global strategy to stop health-care providers from performing female genital mutilation. Geneva: WHO; 2010.

12. Berg RC, Denison E, Fretheim A. Psychological, social and sexual consequences of female genital mutilation/cutting (FGM/C): a systematic review of quantitative studies. Oslo: Nasjonalt Kunnskapssenter for Helsetjenesten; 2010.

13. European Institute for Gender Equality (EIGE). Female genital mutilation in the European Union and Croatia. Vilnius: EIGE, European Union; 2013.

14. Bagnol B, Mariano E. Gender, Sexuality and Vaginal Practices: DAA, FLCS, UEM; 2012. 15. Isa AR, Shuib R, Othman MS. The practice of female circumcision among Muslims in Kelantan, Malaysia. Reproductive Health Matters 1999;7:137-44.

16. Asali A, Khamaysi N, Aburabia Y, Letzer S, Halihal B, Sadovsky M, et al. Ritual female genital surgery among Bedouin in Israel. Archives of Sexual Behavior 1995;24:571-5.

17. United Nations Population Fund (UNFPA). Project embera-wera-An experience of cultural change to eradicate female genital mutilation in Colombia - Latin America. New York: United Nations Population Fund; 2011.

18. Yoder PS, Khan S. Numbers of women circumcised in Africa: The production of a total. Calverton: Macro International Inc.; 2008.

19. UNICEF. Female genital mutilation/cutting. A statistical overview and exploration of the dynamics of change. New York: UNICEF; 2013.

20. Barreto S, Cunha V, Vicente L, Campos A. Mutilação genital feminina: o que sabem os profissionais de saúde? Acta Obstet Ginecol Port 2013;7:89-94.

21. Cunha MI. Género, cultura e justiça: a propósito dos cortes genitais femininos. Análise Social 2013;XLVIII:834-56.

22. Leitão HM. A mutilação fenital feminina à luz do Direito Penal português: da necessidade de alteração do seu regime legal. Revista do Ministério Público 2013;136:99-121. 
23. Istituto Piepoli. Valutazione quantitativa e qualitativa del fenomeno delle mutilazioni genitali in Italia. 2009; available from: http://www.pariopportunita.gov.it.

24. Kőszeghy L. FGM prevalence in Hunagry - estimation. 2012; available from: http://mona-alapitvany.hu.

25. Bansal S, Breckwoldt M, O'Brien GS, Mbugua S. Female Genital Mutilation: Information for Health-Care Professionals Working in Ireland. 2nd ed. Dublin: AkiDwA; 2013.

26. Terre des Femmes. Dunkelzifferstatistik zur weiblichen Genitalverstümmelung in Deutschland. 2013; available from: http://www.frauenrechte.de/online/index.php.

27. Exterkate M. Female genital mutilation in the Netherlands - prevalence, incidence and determinants. Utrecht: Pharos Centre of Expertise on Health for Migrants and Refugees; 2013. 28. Dubourg D, Richard F. Etude de prévalence des femmes excisées et des filles à risque d'excision en Belgique. 2014; available from: http://www.itg.be.

29. Macfarlane A, Dorkenoo E. Female genital mutilation in England and Wales: updated statistical estimates of the numbers of affected women living in England and Wales and girls at risk. Interim report on provisional estimates. London: City University London \& Equlity Now; 2014.

30. Frade A, editor. Por nascer mulher... Um outro lado dos direitos humanos. Lisboa: Associação para o Planeamento da Família; 2007.

31. Thierfelder C, Tanner M, Bodiang CMK. Female genital mutilation in the context of migration: experience of African women with the Swiss health care system. The European Journal of Public Health 2005;15:86-90.

32. Lisboa M, Barroso Z, Patrício J, Leandro A. Violência e género - Inquérito nacional sobre a violência exercida. Lisboa: Comissão para a Cidadania e Igualdade de Género; 2009.

33. Dubourg D, Richard F, Leye E, Ndame S, Rommens T, Maes S. Estimating the number of women with female genital mutilation in Belgium. The European Journal of Contraception and Reproductive Health Care 2011;16:248-57. 
34. Lisboa M, Cerejo D, Teixeira AL, Santana R, Frade A, Moreira C, et al. Mutilação Genital Feminina em Portugal: prevalências, dinâmicas socioculturais e recomendações para a sua eliminação. Vila Nova de Famalicão: Húmus; 2015.

35. Magnani R, Sabin K, Saidel T, Heckathorn D. Review of sampling hard-to-reach and hidden populations for HIV surveillance. Aids 2005;19:S67-S72.

36. Raymond HF, Ick T, Grasso M, Vaudrey J, McFarland W. Resource guide: time location sampling (TLS). San Francisco, CA: San Francisco Department of Public Health HIV Epidemiology Section, Behavioral Surveillance Unit; 2007.

37. United Nations High Commissioner for Refugees (UNHCR). Too much pain. Female genital mutilation \& asylum in the European Union. A statistical overview. Brussels/Geneva: UNHCR; 2013.

38. United Nations High Commissioner for Refugees (UNHCR). Too much pain. Female genital mutilation \& asylum in the European Union. A statistical update (March 2014). Brussels/Geneva: UNHCR; 2014.

39. Conselho Português para os Refugiados (CPR). Protecção internacional em Portugal 2014. CPR; 2015 [18/08/2015]; available from: http://www.cpr.pt/.

40. Allotey P, Manderson L, Grover S. The politics of female genital cutting in displaced communities. In: Green J, Labonté R, editors. Critical perspectives in Public Health, Oxon: Routledge; 2008, p. 192-202. 


\section{Figure captions}

Figure 1. Distribution of women (15 years or older) who have undergone $F G M / C$, living in Portugal, per district 